Bulletin of the Natural History Museum, 2015, 8: 7-19.

Received 13 May 2015; Accepted 15 Sep 2015.

doi: $10.5937 /$ bnhmb $1508007 \mathrm{~N}$

UDC: 551.312:551.791(497.113); 551.312:551.791(497.11-11)

Original scientific paper

\title{
STRATIGRAPHICAL POSITION OF PLEISTOCENE FLUVIAL DEPOSITS OF SOUTHEASTERN SREM AND THE DANUBE TERRACES IN EASTERN SERBIA
}

\author{
DRAŽENKO NENADIĆ ${ }^{1}$, TIVADAR GAUDENYI ${ }^{2}$, KATARINA BOGIĆEVIĆ ${ }^{3}$, \\ MERI GANIĆ ${ }^{1}$ \\ ${ }^{1}$ University of Belgrade-Faculty of Mining and Geology, Department of Historical \\ and Dynamic Geology, Kamenička 6, 11000 Belgrade, Serbia, \\ e-mail: drazenko.nenadic@rgf.bg.ac.rs \\ ${ }^{2}$ Geographical Institute "Jovan Cvijič", Serbian Academy od Sciences and Arts, \\ 11000 Belgrade, Djure Jakšića 9, Serbia \\ ${ }^{3}$ University of Belgrade, Faculty of Mining and Geology, Department of \\ Palaeontology, Kamenička 6, 11000 Belgrade, Serbia
}

Pleistocene fluvial deposits have a significant distribution in Serbia, especially in the riparian area of the Danube and Sava in the southern part of the Pannonian basin. In this region these sediments are almost universally overlain by younger Pleistocene or Holocene deposits, and their thickness varies from 10 to 40 meters. Deposits of similar characteristics, that could be correlated to the synchronous ones in southern Srem, form high terraces of the Danube valley system. Morphologically, these terraces are of erosional-accumulation character. Some preQuaternary deposits of different composition and age are situated beneath the Pleistocene fluvial deposits. Significant height differences among these deposits in the part of southern Srem connected to the high terraces of the Danube are the consequence of differential tectonic movements which were expressed in subsidence of the Panonnian basin, and in stagnation or uplifting in the river valleys.

Key words: Pleistocene, stratigraphy, fluvial deposits, southern Srem, Danube terraces. 


\section{INTRODUCTION}

Pleistocene fluvial deposits represent alluvial deposits of enhanced thickness. They are characterized by cyclic shift of deposits of riverbed, floodplain and oxbows in several sedimentation cycles. These deposits have a significant distribution in the area of Serbian part of the Pannonian basin, but similar deposits also build high terraces of the valley systems of the Danube and Morava (Rakić \& Simonović 1997). In the area of eastern Srem they are mostly covered by loess deposits of younger Pleistocene age or by river sediments of Holocene age, while they are underlain by sediments of earlier, in some places even Neogene age. Terrace levels are of erosional-accumulation character, and pre-Quaternary deposits of different composition and age lie beneath the Pleistocene fluvial deposits. In this work the compilation data obtained from several boreholes in the area of southeastern Srem are used (Knežević et al. 1998, Jeveremović \& Kuzmić 1999, Nenadić 2003, Nenadić et al. 2009, 2013, Nenadić \& Bogićević 2014) and also some data from earlier literare on high Danube terraces in the area of Kladovski Kluč, Danube valley upstream from Golubac to Kostolac and Brza Palanka in Negotin Krajina (Rakić 1972, 1977, 1990, Rakić \& Simonović 1997) (Fig. 1).

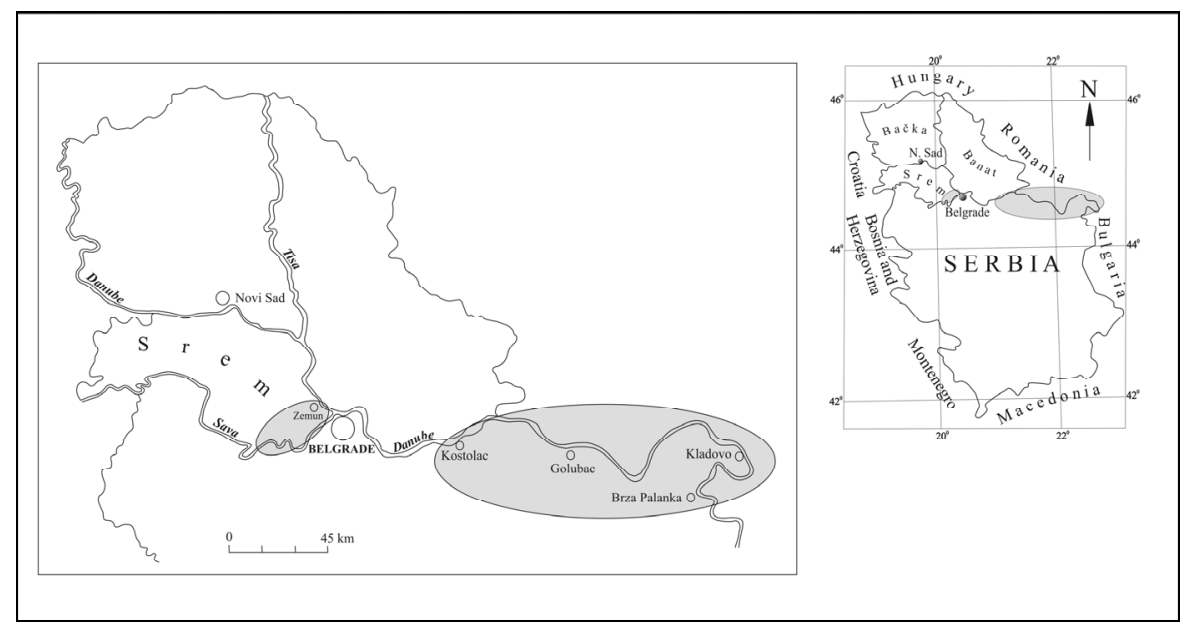

Fig. 1. - Geographical sketch of the investigated area.

\section{MATERIAL AND METHODS}

In this paper material from several boreholes from the area of southern Srem has been sampled and used. A few research methods have been applied: paleontological analysis (mainly of mollusc and ostracod fauna), sedimentological-petrological and classical stratigraphical principles of superposition. 
Petrological composition of gravels was identified macroscopically. For the grain size analysis of clayey fractions the pipette method based on the Stokes law has been applied. In some gravel fractions roundness and sphericity of pebbles have been evaluated (e.g. Grubić et al. 1996).

The remains of molluscs and ostracods were picked out under a binocular microscope and determined to the level of species when possible (e.g. Rabrenović et al. 2003). When no fossils were available, the age of deposits was estimated by the principle of superposition.

The terms "Quaternary" and "Pleistocene" are used according to the latest (2009) recommendations of the International Union for Geological Sciences (IUGS) and the International Commission on Stratigraphy (ICS): the Pleistocene includes the Gelasian Stage/Age, and begins about 2.6 million years ago.

\section{STRATIGRAPHY AND LITHOLOGY}

\section{Southern Srem}

The Pleistocene fluvial deposits of southeastern Srem, known as "Beds with Corbicula fluminalis" (,slojevi sa Corbicula fluminalis") and "Makiš Deposits" (,Makiški slojevi“) by Laskarev (1938) and Stevanović (1977) are lithologically made of cyclical alternation of typical riverbed deposits (sands, gravels) and sediments of flood phase (silts and partly clays) that could be observed in many places. In some cycles flood deposits are missing and regular multi-phase gradation of material has been formed, with coarser material in the lower, and finer in the upper parts. According to superposition and lithofacial characteristics two cycles of alluvial sedimentation could be singled out in these deposits: older cycle, in which sands and gravels dominate (polycyclic fluvial phase) and younger cycle, made mainly of silts (fluvial-palustrine deposits). Due to often alternation of coarse-grained and fine-grained fraction, in horizontal as in vertical direction, these sediments are also known as "fluvial polycyclic deposits" (Rakić 1985, 1990, Stejić \& Rakić 1998, Nenadić 2003, Nenadić et al. 2001, 2009, 2013).

Beside Corbicula fluminalis (Müller) and Viviparus boeckhi (Halavats) the commonest fossil molluscs in these deposits are: Fagotia acicularis (Férrusac), Fagotia esperi (Férrusac), Lithoglyphus naticoides (Pfeiffer), L. fuscus (Pfeiffer), Amphimelania holandri (Férrusac), Theodoxus transversalis (Pfeiffer), T. danubialis (Pfeiffer), Bithynia tentaculata (Linnaeus), Unio crassus (Philipsson), Pisidium amnicum (Müller) etc. (Nenadić 2003, Nenadić et al. 2001, 2009). 
In the area of southeastern Srem these sediments are mainly deposited over the marsh-lake deposits of Pliocene and older Pleistocene, and only in a small part, in the area of the confluence of the Danube and Sava, they are underlain by Miocene deposits - Pannonian marls and marly clays with microfauna of ostracods and rare remains of fossil molluscs: Gyraulus praeponticus, Congeria banatica, Limnocardium sp. etc. (Knežević et al. 1998, Nenadić 2003, Nenadić et al. 2009). Overlying these deposits are Holocene fluvial deposits connected to the Sava riparian belt or Pleistocene loess deposits distributed across the Srem loess plateau. Thickness of the Pleistocene fluvial deposits varies from 10 to 40 meters (Fig. 3).

\section{Danube Terraces}

Similar deposits make the highest terrace floors in the valleys of the Danube (Dunavski ključ), but also in the area of the valleys of the Zapadna and Južna Morava and Nišava, the Azanja fossil valley etc (Rakić 1972, 1977, 1990, Rakić \& Simonović 1997). They comprise gravels of the high terrace floors, $150-160 \mathrm{~m}, 90-110 \mathrm{~m}$ and 50-60 m. Sediments that make these terraces are characterized by multiple alternation of gravels and sands with occasional occurrences of silts, so $2-4$ accumulation cycles could be discerned, i.e. vertical shift of riverbed deposits (gravels and sands) and flood deposits (silts). These deposits have an increased thickness, with values from 15 to $40 \mathrm{~m}$, while lower terraces (below 50-60 m) are characterized by a normal thickness of alluvium from 3 to $15 \mathrm{~m}$ (Fig. 3).

In the area of Kladovo Ključ fluvial polycyclic sediments are characterized in their lower parts by he presence of gravel and sand, less often silt, with vertical gradation of material according to size and alternation of several classes of sedimentological structures - from finelenticular lamination in silts, to cross-bedding in sands and gravels with cross-bedding or without stratification. Occurrences of cyclical alternation of sediments of riverbed and floodplain point to the fluvial agency, and roundness and orientation of grains to a relatively long transport of material (Rakić 1977).

As regards to fossil record there are findings of Mammuthus meridionalis in the sediments of the Sip terrace (200-210 m of relative height) and the faunal association with Corbicula apsheronica in the lower and ostracod species Cyprynotus salinus, Ilyocypris bradyi etc. in the upper part of the terrace level (90-110 $\mathrm{m}$ of relative height).

In the area upstream of Golubac (between Kostolac and Golubac) the younger part of fluvial polycyclic deposits (beds with Viviparus boeckhi and Corbicula fluminalis) lies discordantly over beds with Unio dawilai, and under the river terraces which are partly cut into them (Rakić, 1977, Rakić \& Simonović 1997). In the lower parts of the series riverbed 
formations (gravels and sands), with faunal association with Viviparus boeckhi and Corbicula apsheronica which indicates warm and humid climate, predominate. The upper part of the series is much finer-grained (silts and clays of the floodplain and oxbows) with fauna which comprises, beside Corbicula fluminalis, forms that are adapted to slow moving and muddy environment.

\section{DISCUSSION}

The Pleistocene fluvial deposits of eastern Srem were, over the years, considered as lacustrine, fluvial-lacustrine or fluvial sediments deposited in Late Pliocene, Plio-Pleistocene, Early or Middle Pleistocene (Laskarev 1937, Stevanović 1977, Rakić 1985, 1990, Nenadić 2003, Nenadić et al. 2013, 2014).

Laskarev (1938) and Stevanović (1977) used the presence of the fossil assemblage of molluscs Corbicula fluminalis (Müller) and Viviparus diluvianus (Kunth.) to determine the age as Middle Pleistocene - Mindel, Mindel/Riss (after the Alpine subdivision of Pleistocene). It has been later found that Viviparus diluvianus corresponds to the species Viviparus boeckhi (Krolopp 1983) which made possible the revision of age of Makiš Beds and a more detailed regional correlation.

Somewhat later, on the basis of lithological an palaeontological features, Laskarev (1951) thought that these deposits represented transitional layers between Neogene and Quaternary, i.e. that in this area lacustrine phasis lasted long in Pleistocene.

Due to the presence of Viviparus boeckhi, Unio sturi and Bithynia crasitessta fluvial polycyclic deposits are, after Rakić (1990), dated as "oldest Pleistocene" (equivalent of the Donau and Günz glacials after the Alpine subdivision of Pleistocene), while younger, fluvial-marsh deposits with Corbicula fluminalis and Planorbis planorbis dentata were deposited in Middle Pleistocene (Mindel).

Stratigraphical considerations and position of the Pleistocene fluvial deposits in the Danube terraces were somewhat more complicated. After Cvijić (1908), Pliocene lakes of the Pannonian and Wallachian basins have long continued to exist in Quaternary, while in Late Pliocene they left traces in the form of three abrasion terraces cut into young valleys of the Black Sea basin. According to his opinion the formation of Đerdap gorge is the consequence of continual cutting of the Danube, which in Late Pliocene was outflowing from the Pannonian into Wallachian basin.

According to Cvijić (1908) there are eight river terraces on the sides of the Djerdap gorge cut into the so-called "Pontian valley floor" or the 
central plain of the former strait between the Pannonian and Wallachian basin (Fig. 2). The highest three: the Sip terrace (200-210 $\mathrm{mrh}=$ meters of relative height), Brza terrace (150-160 mrh) and Ključ terrace (90-110 $\mathrm{mrh}$ ) belong to Late Pliocene; lower three: Kosovica terrace (55-65 mrh), Turnu Severin terrace (27-35 $\mathrm{mrh}$ ) and Kladovo terrace (10-20 $\mathrm{mrh}$ ) belong to Pleistocene; the floodplain terrace and recent alluvial plain (4-7 mrh) are of Holocene age.

It should be taken into consideration that in the time of making Cvijić's stratigraphical scheme Quaternary boundary was officially placed just below Middle Quaternary (Mindel, after the Alpine subdivision of Pleistocene).

The high Danube terraces of 200-210, 150-160 and 90-110 mrh represent, according to Stevanović (1951) an equivalent of Levantine beds, while Marković-Marjanović (1967) considered the terrace of 90-110 m, after the comparison with Romanian and Bulgarian deposits as an equivalent of Villafranchian.

The post-Pontian tectonic movements and sudden withdrawal of water from the Pannonian and Wallachian basin in Middle Pliocene, led to formation of complicated circulated aquatoria in Plio-Pleistocene (Eopleistocene), ending with Middle Pleistocene (Mindel). In those aquatoria fluvial polycyclic sediments were accumulated, and they lie discordantly over Pontian and Lower Paludina beds (Rakić 1977).

Since within the terrace sediments that (according to Cvijić) belong to Late Pliocene the elements of lacustrine depositional areas were not observed (abrasion forms, horizontal facial zonation, very rare horizontal bedding or its complete absence etc.), Rakić and later advocates of a limnic genesis often referred to the mentioned deposits as fluvial-lacustrine.

According to Rakić $(1977,1997)$ in the area of Kladovo Ključ on the basis of finding Mammuthus meridionalis in sediments of the Sip terrace (200-210 mrh) and a faunal association with Corbicula apsheronica in the lower and ostracods Cyprynotus salinus, Ilyocypris bradyi etc. in the upper part of the level 90-110 mrh, the older part of polycyclic deposits could be most precisely correlated with Romanian, i.e. Lower Levantian beds of Romania, while the terraces of Brza (150-160 mrh) and Ključ (90-110 mrh) were formed in Early Pleistocene (Donau and Günz phases after the Alpine subdivision of Pleistocene).

In the Danube valley, upstream of Golubac (between Kostolac and Golubac), after Rakić (1972, 1977) and Rakić and Simonović (1997), Pleistocene fluvial deposits overlie beds with Unio davilai. Beds with Unio davilai overlie discordantly Pontian and other Neogene deposits, and underlie a formation synchronous with beds with Viviparus boeckhi and Corbicula fluminalis. Irregular facial changes of these deposits in 
horizontal and vertical direction, cross-bedding and unionid fauna define together deposition of material by meandering river as in the high terraces in Kladovo Ključ. Fauna with Unio davilai, U. flabelatiformis, U. arca etc. is usually referred to as Lower Levantine or Akchagilian faunal complex, i.e. synchronous with Middle Paludina beds of the Pannonian basin. Pleistocene fluvial deposits (beds with Viviparus boeckhi and Corbicula fluminalis) overlie discordantly beds with Unio davilai (i.e. Middle Paludina beds), and lie beneath the river terraces into which they are partially cut. The lower, coarser-grained part of these deposits (riverbed deposits) with the faunal association of Viviparus boeckhi and Corbicula apsheronica would belong, according to Rakić (1977), to Early Pleistocene (phases Donau and Günz after the Alpine subdivision of Pleistocene). The upper, finer-grained part of the series (deposits of floodplain and oxbows) with Corbicula fluminalis would belong to Middle Pleistocene (Mindel, after the Alpine subdivision of Pleistocene).

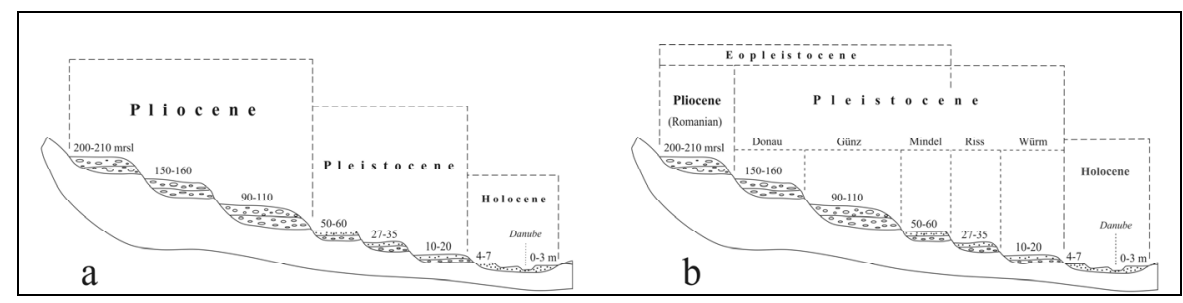

Fig. 2. - Stratigraphical position of the river terraces of the Danube after:

a) Cvijić (1908) and b) Rakić (1990).

According to Rakić and Simonović (1997) the upper part of polycyclic sediments is synchronous with Middle Paludina beds with Corbicula apsheronica, while lower parts, with more silts and clays, are of "Mindel" age; however, the reason for separation several different species of Corbicula is not clear enough.

\section{CONCLUSION}

There are big differences between alluvial deposits which form the Danube terraces and those in the Pannonian basin. They are reflected in lithofacial composition, thickness of deposits and dynamics of deposition.

In the area of eastern Srem Pleistocene fluvial deposits are accumulation in character, so the pre-Quaternary deposits are not detected on the surface, as is the case in the Danube terrace. According to the shape of alluvial plain, lithofacial characteristics and dynamics of the sedimentation processes it could be concluded that Pleistocene fluvial deposits were made in very wide alluvial plains which was formed by the 
action of meandering rivers. Cross lamination and palaeontological content of the mentioned deposits confirm that deposition took place in restless and mobile water environment, and great quantities of sand and gravel obviously testify about warm and wet climate with abundant precipitation.

Accumulation parts of all levels of the Danube terraces are formed of heterogeneous or so-called "colourful" well rounded gravels that belong to riverbed deposits. Floodplain deposits, which overlie the mentioned deposits, are of significantly lesser thickness and made of silts. All lithological members can be found in the form of irregular lenses of different dimensions, which, along with the increased thickness, indicate the lowering of the bottom/floor of the accumulation plain.

With regard to younger terraces, the high Danube terraces are characterized by a great width and significant thickness of deposits (more than $40 \mathrm{~m}$ ), while the thickness of lower terrace deposits varies from 3-15 $\mathrm{m}$. Lithological composition of high terraces points to facies of river deltas and complex floodplains, and frequent changes in horizontal and vertical direction to deposition in flows without permanent position of the riverbed.

Based on the lithological and palaeontological characteristics, Pleistocene fluvial deposits of eastern Srem could be correlated to synchronous ones that form high terraces of the valley system of the Danube (Fig. 3). Significant height differences among these deposits in the part of southern Srem connected to the high terraces of the Danube are the consequence of differential tectonic movements which were expressed in the Panonnian basin in descending of $0.5-2 \mathrm{~mm} /$ year, while in the river valleys were manifested in stagnation or uplift of $0.5 \mathrm{~mm} / \mathrm{year}$.

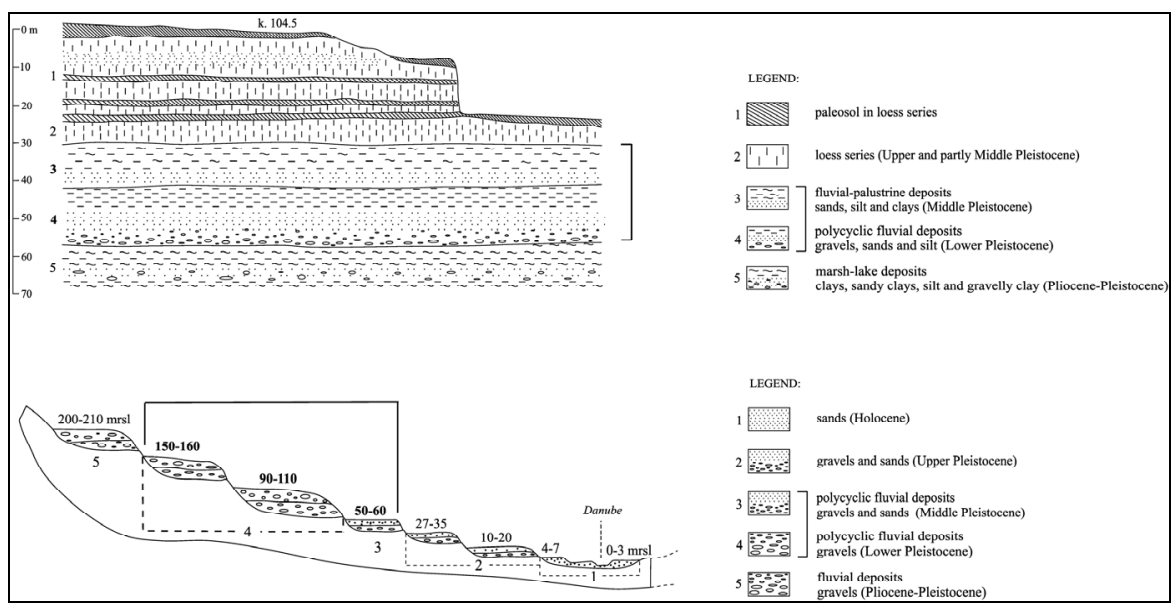

Fig. 3. - Compilation profile of Quaternary sediments in the area of southern Srem and the Danube terraces with the position of Pleistocene fluvial deposits. 
The results from core analysis in the 1990s suggest that the Pleistocene Corbicula species of the Sava riparian area belongs to the temperate stages (equivalent to the interglacials) of the late part of Early and a part of Middle Pleistocene age (Nenadić et al. 2009, 2014). The results also support the conclusions of the analysis of the Hungarian sites by Krolopp (2002).

On the basis of recent studies and the revision of the guide species, such as Corbicula fluminalis (Müller), Viviparus boeckhi (Halavats) and Fagotia esperi (Férrusac), Pleistocene fluvial deposits that contain the mentioned species have been dated as the Lower - Middle Pleistocene (Nenadić et al. 2009, Gaudenyi et al. 2015) (Fig. 4).

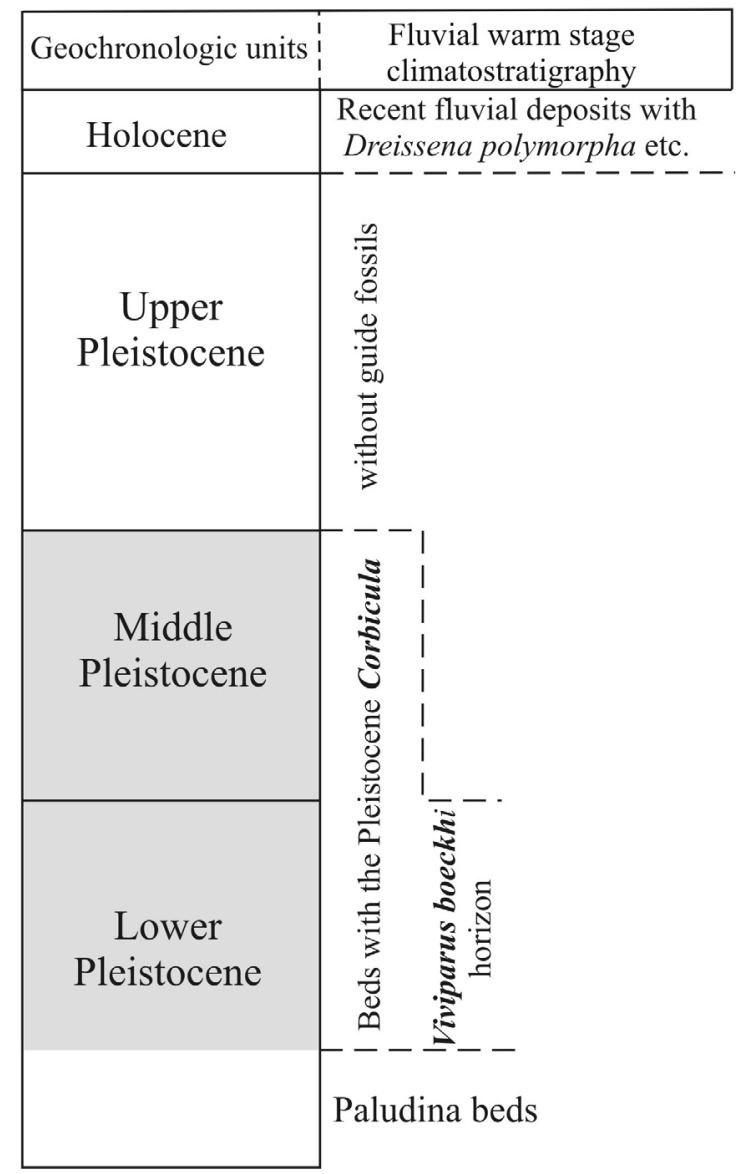

Fig. 4. - Quaternary geochronologic units and the Serbian fluvial warm stage(s) climatostratigraphy.

In the territory of southern Banat Pleistocene fluvial deposits lie over different levels of the Pontian or Paludina Beds (Beds with Viviparus 
vukotinovici), the equivalent of lower part of the Upper Pliocene (Rakić 1985). These deposits are widely spread, forming riparian areas on the right side of the Sava, lower parts of the Kolubara and Tamnava valleys, and further to the south (Stejić 1997, Stejić \& Rakić 1998). At the Belgrade promontory, to the south of the Danube and Sava, the lateral equivalents of these deposits are older Pleistocene polygenetic terrestrial and palustrine deposits (Nenadić 2003). These deposits could be correlated with Lower and Middle Pleistocene fluvial sediments of the oldest (fourth) terrace of the Drava in Croatia and the seventh terrace of the Danube (110-120 m) in the Dacian basin (Peh et al. 1998, Enciu \& Balteanu 2002).

\section{Acknowledgments}

This work was supported by the Ministry of Science and Environment Protection of Serbia, project number 146023 and 177023. The authors are very thankful to the reviewers for their help in improving the manuscript.

\section{REFERENCES}

Cvijić, J. (1909): Jezerska plastika Šumadije. - Glas Srpske kraljevske akademije 79: 1-94. [in Serbian]

Enciu, P., Balteanu, D. (2002): Pliocene-Quaternary paleogeographical evolution of the Dacian Basin (Western Part). In: Geologica Carpathica special issue Proceedings of the XVII. Congress of Carpathian-Balkan Geological Association, Bratislava, Slovakia, September $1^{\text {st }}-4^{\text {th }}$ 2002. - Geologica Carpathica 53 (special issue): 6 p. - Bratislava. [Electronical Form]

Gaudenyi, T., Nenadić, D., Stejić, P., Jovanović, M., Bogićević, K. (2015): The stratigraphy of the Serbian Corbicula beds. - Elsevier. - Quaternary International 357: 4-21.

Grubić, A., Obradović, J., Vasić, N. (1996): Laboratorijska istraživanja. In: Grubić, A., Obradović, J., Vasić, N.: Sedimentologija: 139-163. - Univerzitet u Beogradu, Rudarsko-geološki fakultet, Beograd. [in Serbian]

Jevremović, M., Kuzmić, V. (1999): Zakonitost u taloženju aluvijalno jezerskih i aluvijalno barskih naslaga od leve obale Save prema Batajnici. In: Zbornik referata, 12. Jugoslovenski Simpozijum o hidrogeologiji i inženjerskoj geologiji 2: 115-123. - Novi Sad [in Serbian].

Knežević, S., Nenadić, D., Stejić, P. (1998): Prelesni kvartarni i pliocenski sedimenti Zemuna i Novog Beograda. - Geološki anali Balkanskoga poluostrva 62: 57-73. [in Serbian]

Krolopp, E. (1983): Biostratigraphic subdivision of Hungarian Plesitocene formation according to their mollusc fauna. - Acta Geologica Hungarica 26: 62-89.

Krolopp, E. (2002): Mollusc species of the Hungarian Pleistocene formations. Malakológiai Tájékoztató / Malacological Newsletter 21: 13-18. 
Laskarev, V. (1938): Treća beleška o kvartarnim naslagama u okolini Beograda. Geološki anali Balkanskoga poluostrva 15: 1-35. [in Serbian with French abstract]

Marković-Marjanović J. (1967): Stratigraphy of Quaternary of the Dunavski ključ region and possibilities of correlation with adjoining countries - Romania et Bulgaria. In: VIII Kongres Balkanske geološke asocijacije 1: 417-426. Beograd.

Nenadić, D., Simić, V., Knežević, S. (2001): Stratigrafsko-litološke karakteristike prelesnih pleistocenskih naslaga na prostoru istočnog Srema. - Geološki anali Balkanskoga poluostrva 64: 53-62. [in Serbian]

Nenadić, D. (2003): Pleistocenske naslage istočnog Srema. - Univerzitet u Beogradu, Rudarsko-geološki fakultet, Beograd. (PhD Thesis, manuscr.) [In Serbian with English abstract]

Nenadić, D., Knežević, S., Bogićević, K. (2009): Stratigraphical and Palaeogeographical characteristics of Pleistocene series in the Sava riparian area at Belgrade (Serbia). - Bulletin of the Natural History Museum in Belgrade 2: 63-83.

Nenadić D., Gaudenyi T. (2013): Stratigraphical position of Pleistocene fluvial polycyclic deposits of Serbia. In: Neogene and Quaternary stratigraphy, actual terminology and nomenclature: 44-46. - Serbian Geological Society, Beograd.

Nenadić, D., Bogićević, K. (2014): Pleistocene fluvial deposits from the southeastern Srem and the valleys of the Danube and Morava. In: Zbornik radova XVI Kongresa geologa Srbije, Donji Milanovac, 22-25.05.2014.: 7881. - Donji Milanovac.

Peh, Z., Novosel-Škorić, S., Kruk, Lj. (1998): Discriminant Analysis as a Tool for Distinction of Quaternary sediments in the Region of Đurdevac. - Geologica Croatica 51 (1): 47-58.

Rabrenović, D., Knežević, S., Rundić, Lj. (2003): Metode stratigrafskih istraživanja. In: Rabrenović, D., Knežević, S., Rundić, Lj.: Istorijska geologija: 16-58. - Univerzitet u Beogradu, Rudarsko-geološki fakultet, Institut za regionalnu geologiju i paleontologiju, Beograd. [in Serbian]

Raki, M. (1972): Slojevi sa Corbicula fluminalis kod Brze palanke u Negotinskoj krajini. - Beograd. - Zapisnici srpskog geološkog društva za 1971 godinu: 53-56. [in Serbian]

Rakić, M. (1977): Geneza i stratigrafija kvartarnih sedimenata u slivu Južne i Zapadne Morave (sa kraćim osvrtom na prilike u Dakijskom i Panonskom basenu). - Rasprave Zavoda za geološka i geofizička istraživanja 18: 1-88. [in Serbian]

Rakić, M. (1985): Kvartarni sedimenti južnog Banata, regionalni pregled. - Vesnik geologija, hidrogeologija i inženjerska geologija 43: 5-17. [in Serbian]

Rakić, M. (1990): Regionalni pregled kvartarnih naslaga kotlina i dela Panonskog basena u Srbiji. - Geološki anali Balkanskoga poluostrva 53(1): 315-327. [in Serbian]

Rakić, M., Simonović, S. (1997): Quaternary deposits of Danube valley between Kostolac and Brza Palanka. In: Grubić, A., Berza, T.: Geology of Djerdap Area. - Geoinstitut, Special Edition 25: 81-87. 
Stejić, P. (1997): Geneza i stratigrafija kvartarnih sedimenata Posavo-Tamnave. Univerzitet u Beogradu, Rudarsko-geološki fakultet, Beograd. (master's thesis, manuscr.) [In Serbian with English abstract]

Stejić, P., Rakić, M. (1998): Kvartarni sedimenti donjeg toka reke Save (između Šapca i Obrenovca). In: XIII Kongres geologa Jugoslavije, Regionalna geologija, stratigrafija i paleontologija 2: 247-265. - Herceg Novi. [in Serbian]

Stevanović, P. (1951): Donji pliocen Srbije i susednih oblasti. Geološkopaleontološka studija kaspio-brakičnih facija i produktivnih terena pontijskog kata. - Posebna izdanja, Srpska akademija nauka i umetnosti 187 (2): 1-361. [in Serbian]

Stevanović, P. (1977): Kvartar (Antropogen). Opšti pregled facija i njihovo rasprostranjene s posebnim osvrtom na prelesne, lesne $\mathrm{i}$ antropogene naslage severne Srbije. In: Geologija Srbije 2(3), Stratigrafija (Kenozoik): 357-417. Zavod za regionalnu geologiju i paleontologiju RGF-a, Univerzitet $u$ Beogradu, Beograd. [in Serbian]

\title{
СТРАТИГРАФСКА ПОЗИЦИЈА ПЛЕИСТОЦЕНСКИХ ФЛУВИЈАЛНИХ НАСЛАГА ЈУГОИСТОЧНОГ СРЕМА И ДУНАВСКИХ ТЕРАСА У ИСТОЧНОЈ СРБИЈИ
}

\author{
ДРАЖЕНКО НЕНАДИЋ, ТИВАДАР ГАУДЕњИ, КАТАРИНА БОГИЋЕВИЋ И \\ МЕРИ ГАНИЋ
}

\section{Р Е 3 И М Е}

Флувијалне наслаге плеистоцена представљају алувијалне творевине повећане дебљине које се одликују цикличном сменом седимената корита, поводња и старача изражених у више седиментационих циклуса. Ове наслаге познате и под називом ,речне полицикличне“ распрострањене су на подручју српског дела Панонског басена, а творевине сличних карактеристика граде и високе терасе долинских система Дунава и Мораве. Дебљина им варира у распону од 10 до 40 метара.

На подручју југоисточног Срема ови седименти углавном су прекривени лесним наслагама млађег плеистоцена распрострањене „сремске лесне заравни“ или речним творевинама холоцена везаним за приобаље Саве, док им подину чине старији квартарни седименти, а местимично и наслаге неогена. 
Литолошки, изграђени су од цикличне смене наслага корита (шљунак и песак) и поводња (алеврити и ређе глине). У појединим деловима циклуса недостају наслаге поводња, а правилна вишекратна градација је формирана од у доњем делу крупнијег, до у горњим деловима ситнијег материјала.

У морфолошком смислу, дунавски терасни нивои су ерозионоакумулационог карактера. Испод плеистоценских флувијалних наслага налазе се преквартарне творевине различитог састава и старости. Речне терасе изнад 50-60 метара релативне висине одликују се алувијалним седиментима повећане дебљине, од 15 до 40 метара, док су наслаге у нижим речним терасама класичне дебљине алувијона, која износи 3-15 метара.

Акумулационе делове свих нивоа дунавских тераса изграђује хетерогени или тзв. „шарени“ добро заобљени шљунак који припада наслагама корита. Изнад наведених наслага налазе се творевине поводња, које су знатно мање дебљине и изграђене од алеврита. Сви литолошки чланови појављују се у виду сочива неправилних облика и различитих димензија, што уз повећану дебљину указује на спуштања дна акумулационе равни.

На основу литолошких и палеонтолошких карактеристика плеистоценске флувијалне наслаге источног Срема могу се корелисати са синхроним наслагама високих дунавских тераса. Знатне висинске разлике између плеистоценских алувијалних наслага југоисточног Срема и високих тераса Дунава последица су диференцијалних тектонских покрета који се у Панонском басену огледају спуштањем у распону од 0,5 до 2 милиметара годишње, док се у речним котлинама манифестују стагнацијом или издизањем од 0,5 милиметара годишње. 